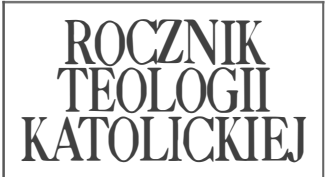

Tom I

Rok 2002

\author{
Ks. Stanisław Urbański
}

UKSW Warszawa

\title{
DUCHOWOŚĆ KOŚCIOłA ZACHODNIEGO
}

Wydaje się, że współczesne zainteresowania duchowością nie są tylko modą powierzchowną. Jest to jeden ze „znaków czasu”, zjawisko, które zasługuje na refleksję teologów i przedstawicieli wielu innych dyscyplin naukowych. Duchowość więc odpowiada na głębokie potrzeby ludzi naszych czasów i daje klucz do zrozumienia współczesnej sytuacji różnorodnych „wyznań" i duchowych tradycji. Zauważamy, że podstawy chrześcijańskiej duchowości są obecnie badane, a nawet krytykowane w sposób kreatywny, ze świeżym spojrzeniem. W rzeczywistości obecna dyskusja wprowadza do chrześcijańskiej duchowości pewną „rewolucję". Wiele elementów z tradycji jest usuwane, zmusza się do powrotu do źródeł i ponownego odkrywania podstawowych zasad. Dlatego otwiera się droga do odnowy chrześcijaństwa stającego twarzą w twarz z kulturowymi wyzwaniami nadchodzącej epoki. Nie wchodząc w szczegółowe dyskusje na temat duchowości współczesnej, należy równocześnie dostrzec możliwość nie tylko autentycznej religijności, lecz także możliwość mistycznych horyzontów współczesnej duchowości. Współcześnie, najbardziej ogólnie ujmując rozumienie duchowości, można by ją sprowadzić do różnych stanowisk (religijnych i ateistycznych), reprezentujących różne typy szkół duchowości, poglądów i interpretacji. Istotne dla nas jest to, iż o życiu duchowym we właściwym tego słowa znaczeniu można mówić tylko w kontekście chrześcijańskiego życia religijnego. Inaczej mówiąc, nie można go rozpatrywać w oderwaniu od tego, co je konstytuuje, tj. w oderwaniu od relacji Misterium Chrystusa. Doświadczenie życia duchowego najogólniej można opisać jako szczególne doświadczenie człowieka, poprzez które zdaje on sobie sprawę (bardziej lub mniej wyraźnie) z bezpo- 
średniego działania Boga na jego osobiste życie religijne. Działanie Ducha Świętego zawsze w ciągu wieków ubogacało życie wiernych Kościoła, tworząc głębię życia duchowego wielu świętych oraz mistyków w żywej wspólnocie Mistycznego Ciała Chrystusa, i stanowi przedmiot teologicznej refleksji naukowej. Trzeba zaznaczyć, że innej od refleksji gnostyków, filozofów czy wyznawców buddyzmu. Jest to duchowość chrystocentryczna, sakramentalna i eklezjalna, a zarazem personalistyczna, dotycząca głębi osobistych doświadczeń i otwarta na to wszystko, co jest znaczące dla każdego człowieka.

\section{1. „Nowy spirytualizm” Europy}

Sobór Watykański II przyniósł organizacyjne i liturgiczne zmiany, przygotowane przez przeobrażenia w myśleniu teologicznym. Ale czy rozpoczął też drogę duchowej przemiany? Niektórzy na tak postawione pytanie odpowiadają negatywnie, przytaczając zjawiska konsumpcjonizmu, ateizmu, neognozy itd. W rzeczywistości Sobór wyszedł naprzeciw pragnieniu dojrzałości duchowej człowieka, ale zarazem zwrócił w krytyczny sposób uwagę na ambiwalentny charakter różnych prądów współczesności. Dzisiaj, ponad trzydzieści lat po jego zakończeniu, „znaki czasu” są już trochę inne niż wtedy. Sobór chciał przygotować Kościół na życie w zsekularyzowanym społeczeństwie i na dialog z sekularyzmem oraz ateizmem. Obecnie zauważamy potrzebę podjęcia dyskusji z nowymi odmianami religijności oraz z tendencjami "totalnego" wypierania religii z życia Europy. Dlatego mówimy o epoce "postsekularnej”, w której mamy do czynienia z postmodernistyczną religijnością, która sama jest często inspirowana pozachrześcijańskimi duchowościami i tradycjami ${ }^{1}$. „Chrześcijaństwo - pisze Jan Paweł II - trzeciego tysiąclecia będzie musiało coraz lepiej zaspokajać potrzebę inkulturacji. Pozostając w pełni sobą i dochowując bezwarunkowej wierności orędziu ewangelicznemu oraz kościelnej tradycji, będzie przybierało także oblicze różnych kultur i narodów, w których zostanie przyjęte i zapuści korzenie"2. Czyni to obecny Papież poprzez projekt „nowej ewangelizacji”.

Rodzi się nowa duchowość akulturowa i inkulturowa, która swoją relację do kultur wyraża w terminach wcielenia i transcendencji. Dlatego przyjmuje zasadę chrystonomiczną, czyli zasadę wcielenia się w to, co ludzkie, wcielenia się $\mathrm{w}$ historię i jej przemianę nie tylko w ramach kultury przesz-

1 T. Halik, Mistyka a duchowa diagnoza nowych czasów, „W drodze” 1998, nr 12, s. $72-73$.

2 Jan Paweł II, Novo Millennio Ineunte, nr 40. 
łości, ale w formie nowego języka. Wynika to z tego, że doświadczenie Boga jest związane z kontekstem kulturowym. Duchowość bowiem naznaczona jest aktualną sytuacją kulturową, socjopolityczną i socjoeklezjalną. A to wymaga pewnego rodzaju kenozy samego przesłania ewangelicznego istniejącego wewnątrz każdej kultury, narodu i pokolenia, po to, aby przemienić jego oblicze podobnie jak to uczyniło Słowo Wcielone. Również duchowość chrześcijańska musi się „wcielić” w kulturę, w doczesność, by dokonać consecratio mundi stwórczego dzieła Boga nieustannie dokonującego się poprzez twórcze działanie chrześcijanina. Chodzi tutaj o głębokie życie duchowe człowieka, małżonków, rodziny, które byłoby wyrazem inkarnacyjnej działalności chrześcijaństwa, odkupionej chrześcijańskiej egzystencji, po to, aby postępować zgodnie z porządkiem Bożym. W ten sposób duchowość chrześcijańska, jako istotowo włączona w życie stworzonego świata, jest otwarta, wyzwolona $z$ izolacji czy z tendencji wykluczenia. Jest to duchowość „zanurzenia", czyli włączenia w świat i w życie. W rzeczywistości chodzi o to, aby chrześcijanin pośród zajęć życia i jednocześnie integrując wartości ziemskie oraz możliwości wykonywania zawodu mógł realizować ideał świętości we własnym stanie życia (małżeńskiego, świeckiego, kapłańskiego itd.). Dlatego „ruch obecności duchowości” dowartościowuje nowe rodzące się formy duchowości, takie jak pracy, apostolatu, przedsiębiorstwa, uniwersytetu itd. ${ }^{3}$

Zauważamy potrzebę wypracowania nowego stylu duchowego życia, które oddaliło się zwłaszcza na Zachodzie od pobożności tradycyjnej, a nie znalazło jeszcze egzystencjalnych utrwalonych form płynących z Tajemnicy Wcielenia, która łączy się z losem człowieka współczesnego. Powstałe ruchy duchowe objawiające współczesną kulturę, a właściwie w jej ramach Ewangelię, są nie tylko narzędziem ewangelizacji, ale są same ewangelizowane. Dlatego realizują postawę Marty i Marii, a więc jednocześnie postawę działania i kontemplacji, co stanowi syntezę dojrzałego chrześcijanina. Doświadczenie kontemplacji powinno przenikać aktywne życie społeczeństwa, zarówno polityczne, jak i ekonomiczne, treścią Ewangelii. Wówczas idea Boga gnostyków w świetle duchowości ateistycznej, szczególnie propagowana przez filozofów, ignorantów teologii, nie będzie miała racji bytu. Żywy Bóg działający zawsze przez Wcielenie swego Syna doświadczanego i przeżywanego w kontemplacji oraz w sakramentach świętych nie budzi lęku wobec wyzwań obecnej kultury. Jedynie duchowość akulturowa i jednocześnie zakorzeniona $\mathrm{w}$ bogactwach przeszłości potrafi włączyć się w dzisiejsze problemy świata związane $z$ momentem historycznym, ze środowiskiem itd.

3 L. Boriello, G. della Croce, B. Secondin, Historia duchowości, tł. M. Pierzchała, Kraków 1998, t. VI, s. 378-382. 
Jest to duchowość kontemplacyjno-czynna. Ten aspekt duchowości jawi się jako nieodzowny wymiar chrześcijańskiego świadectwa. Dlatego pisze Jan Paweł II: „należy odrzucać pokusę duchowości skupionej na wewnętrznych, indywidualnych przeżyciach, którą trudno byłoby pogodzić z wymaganiami miłosierdzia, a ponadto $\mathrm{z}$ logiką Wcielenia i ostatecznie nawet z chrześcijańską eschatologią. Choć uświadamia nam ona względność historii, nie zwalnia nas bynajmniej z obowiązku budowania jej" ". Już wcześniej w nauce Soboru widzimy, że duchowość chrześcijańska „nie odwraca człowieka od budowania świata i nie zachęca go do zaniedbywania dobra bliźniego, lecz raczej silniej wiąże go z obowiązkiem wypełniania tych rzeczy" (KDK 34). Można ją nazwać duchowością rzeczywistości ziemskich. Musi się ona prezentować jako duchowość tego, czym człowiek żyje dzisiaj, w radykalnym zaangażowaniu na rzecz Królestwa Bożego. Duchowość człowieka włączona w historię jest duchowością pielgrzymowania, aby wcielić Boga w zawsze zmieniające się warunki historyczne.

Innym wymiarem obecnej duchowości Kościoła Zachodu jest jej charakter ewangeliczny. Jan Paweł II uważa, że jest to jedno z najważniejszych zadań stojących przed Kościołem na progu nowego tysiąclecia. Związane jest ono $z$ nową sytuacją, która „staje się coraz trudniejsza i bardziej zróżnicowana w związku z globalizacją oraz powstawaniem nowych i zmiennych współzależności między narodami i kulturami" ${ }^{5}$. Chodzi o to, aby współczesny chrześcijanin, kontemplujący i działający, podjął ewangelizację w celu złagodzenia różnic pomiędzy różnorakimi duchowościami z przeszłości poprzez ich ożywienie i dostosowanie do potrzeb religijnych obecnego człowieka. To ożywienie dokonuje się poprzez powrót do duchowości liturgicznej, w której ludzie wierzący doświadczają obecności Jezusa, a także poprzez duchowość patrystyczną, będącą autentycznym świadectwem wiary.

Duchowość ewangeliczna - aktualnie realizowana - wyraża się w duchowości mistycznej, ekumenicznej, międzynarodowego dialogu ${ }^{6}$, a także w duchowości męczeństwa. „Nasza epoka - pisze Jan Paweł II - jest szczególnie bogata w świadków, którzy w taki czy inny sposób potrafili żyć Ewangelią mimo wrogości otoczenia i prześladowań, składając często najwyższe świadectwo krwi" ?.

W perspektywie tej fundamentalnej opcji duchowości ewangelicznej mieści się obszar duchowości poszanowania praw ludzkich, życia każdej ludz-

\footnotetext{
4 Jan Paweł II, Novo..., s. 51.

5 Tamże, s. 40.

6 Tamże, s. 41, 48.

7 Tamże, s. 41.
} 
kiej istoty, pokoju, istnienia narodów, szczególnie biednych, i ludzi bezrobotnych lub różnorodnie wykorzystywanych. Innymi słowy duchowość ewangeliczna (współczesna) stara się przywrócić właściwe proporcje duchowego wnętrza człowieka, jego wymiar ludzki i boski.

W obrazie duchowym Kościoła Zachodniego wyłania się jeszcze duchowość komunii. Jest to, mówi Papież, „spojrzenie utkwione w tajemnicy Trójcy Świętej, która zamieszkuje w nas i której blask należy dostrzegać także w obliczach braci żyjących wokół nas. Duchowość komunii to także zdolność odczuwania więzi z bratem w wierze głębokiej jedności Mistycznego Ciała, a zatem postrzegania go jako „kogoś bliskiego”, co pozwala dzielić jego radości i cierpienia, odgadywać jego pragnienia i zaspokajać jego potrzeby, ofiarować mu prawdziwą i głęboką przyjaźń. Duchowość komunii to także zdolność dostrzegania w drugim człowieku przede wszystkim tego, co jest w nim pozytywne, a co należy przyjąć i cenić jako dar Boży: dar nie tylko dla brata, który bezpośrednio go otrzymał, ale także „dar dla mnie". Duchowość komunii to wreszcie umiejętność „czynienia miejsca” bratu, wzajemnego "noszenia brzemion” (por. Ga. 6, 2) i odrzucania pokus egoizmu, które nieustannie nam zagrażają, rodząc rywalizację, bezwzględne dążenie do kariery, nieufność, zazdrość. Nie łudźmy się, bez takiej postawy duchowej na niewiele zdałyby się zewnętrzne narzędzia komunii. Stałyby się bezdusznymi mechanizmami, raczej pozorami komunii niż sposobami jej wyrażania i rozwijania" 8 .

Z podanych definicji Jana Pawła II wynika, że duchowość komunii aktualnie realizowanej zawiera braterstwo wspólnoty ludzkiej; otwartość na szeroko rozumiany uniwersalizm, z pominięciem różnorodnych barier; zdolność do przyjęcia i uświęcenia rzeczywistości ziemskich, uświęcenia techniki i jej wytworów. Ponadto uznaje komunię ludzką za „sakrament” osobistej komunii z Bogiem, uważa bliźniego za najkrótszą drogę prowadzącą do Jezusa $^{9}$.

\section{Nowe formy duchowości Europy}

Nowe treści życia duchowego zrodziły wielorakie nurty odnowy w formie ruchów religijnych skupionych wokół jakiegoś nurtu myśli lub jakiegoś mistrza duchowości, istniejącej potrzeby Kościoła we współczesnym świecie w formie ruchów modlitewnych lub nowego mistycyzmu, monastycyzmu itd.

8 Tamże, s. 43.

9 L. Boriello, G. della Croce, B. Secondin, Historia..., s. 387. 
Współczesne ruchy duchowe

Pomijając dokładną ich analizę, ogólnie można wymienić ruchy skupione wokół odpowiednich celów: ruchy rodzinne, apostolskie - pragnące pogłębienia życia duchowego świeckich. Do tego dochodzą liczne grupy modlitewne, grupy biblijne, ewangeliczne, maryjne, wspólnoty osób konsekrowanych, kapłańskie, zakonne itd. Nie można pominąć wielkiego ruchu odnowy charyzmatycznej, oazowej i neokatechumenalnej. Wszystkie te ruchy duchowe zrodziły się z głębokiego doświadczenia Boga oraz Ducha i są znakiem współczesnej historii Kościoła. Duchowość tych ruchów pragnie aktualizować to, czego współczesna teologia duchowości uczy o świętości człowieka, realizując humanizm poprzez świadectwo wzajemnej miłości, doświadczenie duchowe, duchowość pustyni, mistycznej samotności itd.

\section{Dwa typy duchowości}

Pierwszy, negatywny, wyraża typ pobożności „racjonalnej”, „zimnej”, która żyje w sytuacjach bliskich praktycznemu ateizmowi, sama jednak nie jest ateistyczną. Najczęściej reprezentują ten typ duchowości tzw. intelektualiści katoliccy, broniący katolicyzmu „intelektualnego” o zabarwieniu antropologicznym, nie doceniając zbyt mocno Transcendencji. Posiadają określoną duchowość chrześcijańską opartą na rozumieniu prywatnej modlitwy, bez doświadczalnego korzystania z Eucharystii. Wcześniej czy później przechodzą przez czyściec współczesnego racjonalizmu, sprowadzając często pojęcie Boga do idei dyskutowania.

Drugi typ duchowości charakteryzuje się przebudzeniem religijnym o charakterze mistycznym, gdzie element doświadczalny przeważa nad intelektualnym. W przeszłości mistyka nie była obiektem stałych zainteresowań krytycznego umysłu, była raczej rozumiana jako „nadbudowa” dla doskonałych albo dla tych, którzy o tę doskonałość ze względów profesjonalnych się starali. Dzisiaj zauważa się, że odnowa chrześcijaństwa rozpoczyna się od pogłębionego, osobistego, religijnego doświadczenia. W teologicznych terminach oznacza to uchwycenie relacji kontaktu człowieka z Bogiem Trynitarnym, objawiającym się w Chrystusie i doświadczalnym w Duchu Świętym. Dlatego wielu chrześcijan, nie znajdując możliwości pogłębienia swojego doświadczenia religijnego, szuka doświadczeń w pozaracjonalnej religijności. W duchowości poszukiwanej przez współczesnego człowieka nie ma już miejsca na rygorystyczne koncepcje, jest natomiast na przeżycie duchowego doświadczenia. Ukazuje ona bowiem drogę, dzięki której w sposób najbliższy Wcielenia może chrześcijanin żyć wiarą w Chrystusa i jej wy- 
maganiami w konkretnym życiu. Bez miejsca na intensywne doświadczenie wewnętrzne będzie trudno żyć Europejczykowi w kulturze masowej społeczeństw technologicznie zaawansowanych. Dlatego istnieje dzisiaj tendencja do uprzywilejowania doświadczenia Boga, które jest zarazem ludzkie, gdyż odbierane jest na wszystkich poziomach osobowej egzystencji człowieka.

\section{Zryw mistycyzmu}

Zauważa się dzisiaj nie tyle powrót do mistyki, co szczególne zainteresowanie współczesnymi mistykami i samym zjawiskiem mistycyzmu. Nie zgłębia się teologii życia mistycznego, a ignorancja w tej dziedzinie powoduje, że zwraca się uwage jedynie na nadzwyczajne zjawiska mistyczne, na zewnętrzne życie ich autorów, na cudowne oddziaływanie. Wszystko to sprawia, że ich postawa zachwyca współczesnego człowieka, nawet dalekiego od wiary. Nieznajomość teologii mistyki rekluzji, oblubieńczej i posłania powoduje nierozumienie realizacji głębokiego życia duchowego. A z drugiej strony zainteresowanie „mistykami” ujawnia nową wrażliwość na transcendentny wymiar życia człowieka. Mistyka posłania (powołania) rodzi nową solidarność ludzkości i ujawnia się w dążeniach ludzi podejmujących akcje społeczne, polityczne na rzecz przemiany porządku społecznego, ruchy ekologiczne, broniące natury świata stworzonego przez Boga, ruchy demograficzne i terapeutyczne, promujące twórczość człowieka. Chociaż wiele z nich nie ma zabarwienia religijnego, to jednak zdradzają odcienie religijności, którac chrześcijanie obecni w nich powinni wyzwalać i rozwijać.

Odkrywają one Bożą transcendencję w codziennej egzystencji, często w interpretacji neognozy, ale są jednocześnie dowodem otwarcia się Kościoła na transcendencję jako konstytutywny element istnienia ludzkiego. Dlatego duchowość chrześcijańska, tak jak w przeszłości, nie może usunąć się na margines życia współczesnego i przez swoją nieefektywność nie dawać odpowiedzi na aktualne wyzwania. Mamy bowiem do czynienia z pewnym przebudzeniem mistycznym, w którym trzeba uchwycić prawidłowe działanie Ducha Świętego, by nie spowodować rozwoju pseudomistyki.

$\mathrm{W}$ istocie podjęcie tego problemu i jego właściwe rozwiązanie posiada istotne znaczenie w życiu duchowym w ogóle. Niezależnie od obiektywnego przekazu doświadczenia mistycznego, np. Faustyna, A. Salawa, M. Darowska, Nastał, Z. Tajber itd., musimy stwierdzić, że w centrum tegó̇ doświadczenia znajduje się osobisty stosunek człowieka do Boga. Pozostaje on też zawsze czymś wyłącznym i niepowtarzalnym niezależnie od epoki (np. św. Jana od Krzyża, św. Franciszka Salezego czy św. Katarzyny ze Sieny), w której się dokonuje i języka, jakim się próbuje go opisać. 
W kontekście więc ludzkiej solidarności, to co przeżywali mistycy, np. „noc ciemna", zyskuje nowe współczesne znaczenie, ponieważ posiada zawsze związek z Chrystusem i nabiera charakteru bardziej uniwersalnego. Autentyczny mistyk nie jest egocentrykiem, ale człowiekiem dla innych. Łamie współczesny egocentryzm, ponieważ jest „posłany” przez Boga z pewnym zadaniem. Widzimy to u św. Faustyny, która otrzymała "posłanie" i wyraziła swoją „dyspozycyjność". Wówczas wszystko co boli w „ciemnej nocy" zjednoczenia z Chrystusem nabiera mistycznego wyrazu jako współuczestnictwo w dziele zbawienia świata (miłosierdzie Boże). Mistyk nie zamyka się na osobistym „samozbawieniu”, ale na pragnieniu zbawienia wszystkich. Dlatego uczestniczy w życiu tego świata, tych ludzi, w sposób dynamiczny.

Holistyczna perspektywa teologii mistycznej nie pozwala zejść na bezdroża modnego gnostycyzmu czy dawnego angelizmu. Przyjmując integralność człowieka, podkreśla pełny wymiar jego dążenia do najwyższej doskonałości człowieczeństwa wraz z naturalnymi możliwościami i uzdolnieniami, ku najwyższej świętości, którą Ojcowie Greccy nazywali „przebóstwieniem”. Świadomość procesu życia mistycznego jest konieczna, ponieważ nie istnieje „bezrozumna mistyka”. Mistycy są też świadkami Kościoła i jego obrońcami, gdyż chronią wspólnotę Ludu Bożego przed pomniejszeniem jego misji, który zawsze odwołuje się do Boga jako swego źródła i celu.

Dzisiaj również i w Polsce rozwija się zainteresowanie mistyką przeżyciową oraz badaniami nad prozą i poezją mistyczną. Szczególnie te ostatnie badania prowadzą filologowie.

Wraz z powrotem do mistyki nastąpił powrót do modlitwy, do doświadczenia modlitwy. Ono stało się też motywem powstawania różnych ośrodków modlitwy i odnowy jej charakteru wspólnotowego. Zrodziło też nawiązanie do duchowości Dalekiego Wschodu, przyczyniając się do wielu wypaczeń.

\section{Duchowość ludowa}

Z koncepcji duchowości w wymiarze indywidualnym i komunii wyłoniła się, dzięki docenieniu duchowego doświadczenia, duchowość ludu. Jej charakterystycznym rysem jest dowartościowanie religijności ludowej, z charakteryzującymi ją tradycjami etnicznymi, społeczno-kulturowymi i folklorystycznymi. Dzisiaj otwarcie się na wartości religijności ludowej następuje szybko. Widać to wyraźnie w sanktuariach, gdzie ludzie swoją duchowość wyrażają w spontanicznej modlitwie, bez pośrednictwa kultury literackiej, niosąc w sobie samych treści symboliki chłopskiej, robotniczej, rzemieślniczej, wiejskiej itd. Przesadny intelektualizm teologiczny odrzucił wszelkie 
praktyki pobożnościowe, nie doceniając w nich wystarczająco rzeczywistości symboliczno-rytualnej, tworzącej kontekst społeczno-kulturowy, będący syntezą wyrażania własnych uczuć religijnych. Dopiero marksizm ukazał całe bogactwo tego, co wyzwala tożsamość duchową mas ludowych. Również ewangelizacja nie doceniająca korzeni kultury religijnej propagowała tylko chrześcijaństwo powierzchowne. Tymczasem rzeczywistość mas ludowych jest rzeczywistością społeczno-polityczną, trwałą, chociaż niejednoznaczną i występującą we wszystkich epokach ${ }^{10}$. Dlatego doświadczenie religijności ludowej powinno być ukierunkowane eklezjalnie jako doświadczenie wspólnoty Ludu Bożego. Ponieważ docenienie tegoż charyzmatu wewnątrz własnej kultury jest autentycznym przejawem charyzmatycznego bogactwa Kościoła ujawniającego się w określonej sytuacji. Nie oznacza to chrześcijaństwa upierwotnionego, które stało się udziałem np. ludu wiejskiego. Przeciwnie, w kulturze mas ludowych znajdują się także liczne religijne treści kultury ludowej, których poziom jest niekiedy z teologicznego punktu widzenia bardzo wysoki. Dotyczy to również całej paraliturgii, wszelkich jej tekstów modlitewnych i muzycznych oraz ikonografii, także gdy idzie o sztukę ludową.

\section{Duchowość nowego wymiaru Europy}

W poszukiwaniu duchowości związanej z życiem, Jan Paweł II wzywa ludzi wierzących, aby całym sercem przejęli się losem człowieka. Właśnie człowieka należy umieścić w centrum duchowości chrześcijańskiej; człowieka biednego, umieszczonego w bogatych społeczeństwach Zachodu lub żyjącego obok, człowieka zapracowanego, bez czasu na odpoczynek, ale szukającego kontaktu z Bogiem poprzez wstawiennictwo Maryi.

\section{Duchowość ubogich}

W Kościele zachodnim coraz bardziej uwydatnia się duchowość ubogich, która jest znakiem profetycznym czasów współczesnych. Faktem jest, że więcej niż dwie trzecie ludności znajduje się w sytuacji, która nie przystoi godności osoby ludzkiej ze względu na brak pokarmu, mieszkania, zajęcia, pracy, wykształcenia. Dlatego tak się dzieje - piszą niektórzy autorzy - że mamy przed sobą efekty porządku skandalicznego i antyewangelicznego.

10 L. Boriello, G. della Croce, B. Secondin, Historia..., s. 403. 
Chrześcijańska duchowość zwraca uwagę na naśladowanie Jezusa, który był biedny z biednymi, który leczył chorych i karmił biednych, głosił nową sprawiedliwość, ale sam umarł „Zwyciężony” przez „sprawiedliwość” (prawo) swego czasu. Chrześcijanin poszukujący naśladownictwa Chrystusa biednego musi być przygotowany na śmierć, opuszczenia i wyrzeczenia, ogołocenia się $\mathrm{z}$ ducha posiadania i bezpieczeństwa doczesnego.

Zasadniczą wartością postawy ubóstwa dla współczesnego człowieka jest demaskowanie wszelkich nadużyć, które wynikaja z nieumiarkowanego zaspokajania potrzeby posiadania. Dla człowieka hołdującego konsumpcjonizmowi połączonemu często z brakiem solidarności międzyludzkiej, chrześcijanin o ukształtowanej postawie ubóstwa staje się znakiem właściwej hierarchii wartości i wezwaniem do jej respektowania. W ten sposób człowiek żyjący ubóstwem staje się dla współczesnego świata znakiem priorytetu osoby nad rzeczami i powołania do bycia darem dla bliźniego w niesieniu pomocy. Z drugiej strony stanowi dla bogatych społeczeństw pewnego rodzaju wyrzut sumienia, wzywający je do nieustannego nawracania się 11 .

Ale największa wartość ubóstwa ewangelicznego tkwi przede wszystkim w jego profetycznej misji. Jest to duchowość, która proponuje preferencyjna i solidarną opcję na rzecz ubogich i coraz pełniejsze utożsamienie się z Chrystusem i ubogimi. Dlatego wśród ubogich tkwi siła ewangelizacyjna, gdyż oni realizują życie duchowe wyrażające się solidarnością, służbą, prostotą i otwartością na przyjęcie daru12. Chrześcijanin będąc biednym musi aktywnie uczestniczyć w historycznych ruchach bieżącej chwili, aby pomóc tworzyć bardziej sprawiedliwy świat jako antycypację pełnego łaski Królestwa Bożego, które jest darem Boga ofiarowanym człowiekowi w Chrystusie. „Dlatego - pisze Jan Paweł II - ewangeliczne ubóstwo przeciwstawia się z mocą bałwochwalczemu kultowi mamony i staje się proroczym zawołaniem skierowanym do społeczeństwa, które żyjąc w wielu częściach świata w dobrobycie, jest wystawione na niebezpieczeństwo utraty poczucia umiaru i świadomości istotnej wartości rzeczy" (VC 90). Zatem ubóstwo staje się służbą innym i dzieleniem się z nimi dobrami na wzór Chrystusa. Ubogi więc to nie ten, kto coś daje, ale ten kto, dając siebie otwiera się na Boga w ludziach. Dopiero tak praktykowane ubóstwo staje się dla aktualnego człowieka i wspólnoty Kościoła, w której on żyje i działa, ubóstwem ubogacającym. Historia Kościoła zna i odnotowuje wiele przykła-

11 H. Wejman, Osiem błogosławieństw ewangelicznych. Nowe perspektywy duchowości, Poznań 2000, s. 28-29.

12 L. Boriello, G. della Croce, B. Secondin, Historia..., s. 503. 
dów w ten sposób realizowanego ubóstwa. Wystarczy chociażby wspomnieć św. Alberta, bł. Anielę Salawę, którzy są modelem chrześcijanina żyjącego biednie i dla biednych. Realizowali oni duchowość miłosierdzia skłaniająca do podejmowania dzieł czynnej i konkretnej miłości wobec każdego człowieka. Duchowość ewangelizacji bez miłosierdzia i świadectwa chrześcijańskiego ubóstwa może pozostać nie zrozumiana i „utonąć w powodzi słów, którymi i tak jesteśmy nieustannie zalewani we współczesnym społeczeństwie przez środki przekazu. Miłosierdzie czynów nadaje nieodpartą moc miłosierdziu słów" 13 .

\section{Znaczenie pobożności maryjnej}

Nie należy sugerować się stwierdzeniem, że pobożność maryjna stanowi specyfikę wyłącznie religijności polskiej. Przeczy temu nie tylko dokumentacja teologiczna od Ewangelii Łukaszowej aż po II Sobór Watykański, ale także analiza duchowości i kultury poszczególnych narodów. Nie trzeba przypominać o tym, że kult maryjny rozwijał się w duchowości chrześcijańskiej, i jak pod wpływem indywidualizmu religijnego, a potem racjonalizmu zrodziła się i rozwinęła walka z tym kultem.

Maryjność nadaje duchowości społeczno-geograficzną i kulturową konkretyzację. Otóż świadomość teologiczna i kulturowa Maryi Królowej oraz dyslokacja miejsc pielgrzymkowych zapewnia duchowości konkretne zakorzenienie geograficzne i kulturowe, osadza ja niejako w rozległym systemie treści religijnych i narodowych. Jest to zatem duchowość o wielkim bogactwie duchowo-kulturalnym, dzięki któremu poszczególne narody odnajdują swoją identyfikację duchową i narodową.

Pomijając znane nieracjonalne zarzuty, trzeba powiedzieć, że duchowość maryjna odegrała i odgrywa rolę wychowawczą, np. ukazuje prawidłową relację do Matki, ma charakter pokutny, rozwiązuje trudny problem cierpienia (Matka Bolesna), propaguje wartości moralne. To dzięki niej duchowość chrześcijańska została pogłębiona, wzbogacona oraz upraktyczniona i mogła stać się częścią integralną życia i kultury Europy. Sanktuaria maryjne stały się zaś ośrodkami rozwoju życia duchowego, skupiającymi myśli i kształtującymi duchowość narodów Europy.

13 Jan Paweł II, Novo..., s. 50. 


\section{Duchowość świętowania}

Na skutek współczesnego pracoholizmu i presji sukcesu wymiar świętowania został nieodpowiednio doceniony w duchowości chrześcijańskiej Zachodu. Odrzucono jego aspekt przebaczenia i autentycznej jedności w Chrystusie z ludźmi. Nie doceniono momentu, w którym człowiek wierzący wyraża swoje odczucia religijne wszystkimi swoimi zdolnościami: inteligencją, wrażliwością, radością, poczuciem rodzinności, zażyłością, przyjaźnią ze światem doczesnym i nadprzyrodzonym. W ten sposób zaczęto obchodzić „święta laickie”, pod wpływem których zrodziła się „teologia święta”, w centrum której jest obecny Lud Boży. Świętowanie przeniknięte liturgią wyraża otwarcie się na transcendencję, pragnienie nawiązania komunii z Bogiem, zaś radość i jedność z braćmi czyni człowieka w jego codziennym życiu „bytem mistycznym”, przestrzenią na działanie Boga.

\section{Zakończenie}

Mówiąc ogólnie, chrześcijanin Kościoła Zachodniego przeszedł transformację od religijności jako wierzenia, do religijności opierającej się na doświadczeniu Boga, które zrodziło duchowość personalistyczną, wewnętrzną, mistyczną. Jednocześnie zrodziło duchowość prywatną i wspólnotową; pragnienie bycia jednostką oraz we wspólnocie; pragnienie wyzwolenia się od świata, w którym nie ma miejsca na poczucie bezinteresowności, świętowania, oświecenia, na skupienie wewnętrzne, a z drugiej strony jego uświęcenia. Wszystko to tworzy nowy ruch, pragnący być „Kościołem od dołu”, Kościołem ubogich w świetle radykalizmu młodych ludzi, ofiarnych i antykonformistycznych, ale obecnych w Kościele. Jest to duchowość powrotu do modlitwy i odnowy ruchów religijnych, grup charyzmatycznych itd.

Dzisiaj w zakres duchowości pojmowanej jako refleksja teologiczna i doświadczenie Ducha wchodzą aktualne problemy życia, które dotykają konkretnego człowieka i konkretną wspólnotę. Zarysowuje się jej obraz o charakterze przeżyciowym i wspólnotowym, nie odrzucającym przeszłości historycznej. Sama duchowość przyszłości, która będzie ciągle szukać nowego języka i nowych form pobożności, aby być chrześcijańską nie może pominąć tej jedności. Wzmacniana coraz częściej powstającymi ośrodkami akademickimi (np. w Polsce) będzie przechodzić z syntetycznych rozważań oraz globalnych ocen w praktykę pogłębionego życia duchowego. Odkrycie duchowego doświadczenia jest fenomenem, który w historii ciągle na nowo zaznacza swą obecność w życịu ludzkości, i w jakiś sposób jest związany z tym, co doko- 
nuje się w społeczeństwie i w kulturze, w duchowym klimacie epoki. Dlatego poszukiwania nowej duchowości zmierzają w kierunku „bezpośredniego religijnego doświadczenia". W tym kierunku również zmierzają badania socjologów, filozofów, psychologów itd. Ale oni spłycają problem duchowości do wymiarów zewnętrznych, do atrakcyjności martwej spekulacji myśli, tymczasem zawiera ona otwarcie na działanie Ducha Świętego, nieznane i nigdy nie sprawdzalne. Królewska droga mistyki wypaczona przez modnych filozofów niewiary staje w centrum współczesnej duchowości. Zyskuje ona nową jakość poprzez swoje korzenie w tradycji oraz poprzez dostrzeganie ewolucyjności sytuacji i potrzeb współczesnego człowieka. 